\title{
The urban growth machine, central place theory and access to open space
}

\author{
Jordan W. Smith ${ }^{\mathrm{a}, \mathrm{b}, *}$, Myron F. Floyd ${ }^{\mathrm{b}}$ \\ ${ }^{a}$ Digital Imagery Visualization Laboratory, College of Natural Resources, NC State University, Raleigh, NC 27695, USA \\ ${ }^{\mathrm{b}}$ Department of Parks, Recreation and Tourism Management, NC State University, Raleigh, NC 27695, USA
}

\section{A R T I C L E I N F O}

\section{Article history:}

Received 1 May 2010

Received in revised form date 21 March 2013

Accepted 25 March 2013

Available online $\mathrm{xxx}$

\section{Keywords:}

Open space access

New economic geography

Urban parks

Geographically weighted regression

\begin{abstract}
A B S T R A C T
The provision of urban open space occurs through political and economic mechanisms that could marginalize racial minority groups. In this research, we explore two competing hypotheses of marginalized access to open space (greenways, parks, and natural areas). The first hypothesis couples Logan and Molotch's "growth machine" theory with the concepts of laissez-faire racism and White privilege. Urban space is conceptualized as contested terrain being sought after by local elites who utilize their political and economic will to co-opt government decision making authority. The second hypothesis-central place theory-posits that access to open space is determined by the spatial patterns of economic agglomeration. Analyzing Raleigh, North Carolina as a case study, the results do not support either the growth machine theory or central place theory. Rather, urban growth is found to have very localized social consequences, seen through variations in different racial/ethnic groups' level of access to open space.
\end{abstract}

(c) 2013 Elsevier Ltd. All rights reserved.

\section{Introduction}

\section{Purpose}

Urban planners and scholars have recognized the benefits of publicly available open space for centuries. ${ }^{1}$ In the United States, the creation of Boston Common in 1640 marked the first act by a government body to set aside land within the city for collective uses such as military training and communal grazing (Cranz, 1982). In the 370 plus years since, public open spaces have become a de facto part of the urban environment. Planners and local government officials frequently cite a generalized set of benefits (e.g., increased recreational opportunities, higher quality wildlife habitat, greater community identity, etc.) when advocating for the development and conservation of urban parks and green spaces. While urban open spaces undoubtedly do provide a whole host of benefits to local neighborhoods, only individuals and groups able to access and utilize these areas can realize desired outcomes. In short, the political and economic decisions that go into planning and developing urban

\footnotetext{
* Corresponding author. Address: Campus Box 8004, Biltmore Hall, NC State University, Raleigh, NC 27695, USA. Tel.: +1 9195153437.

E-mail address: jwsmit12@ncsu.edu (J.W. Smith).

${ }^{1}$ We refer to open space throughout both the literature review and our empirical model as all publically accessible parks, natural areas, and greenways. This classification excludes schoolyards, environmental mitigation areas, gamelands, and paved plazas.
}

open space can be the site of social marginalization. Urban scholars can easily overlook this fact by focusing primarily on market-based mechanisms of urban inequality (e.g., housing, access to diverse industrial sectors, etc.). Urban development, including decisions about where to cite urban open spaces, occurs through the actions of individuals who are often simultaneously engaged in public as well as private realms (Domhoff, 1990). In this research, we present the basic proposition that public open space, being a product of the urban political economy, can marginalize racial and ethnic minorities from the benefits of parks and open space. Explicitly, we examine the hypothesis that local government actors can and do manipulate public benefits by creating and conserving public open space in predominantly White neighborhoods while allowing commercial and industrial development to occur in neighborhoods with large proportions of minority populations. This hypothesis represents a coupling of Logan and Molotch's "growth machine" theory (2007) with the notions of laissez-faire racism (Bobo, Kluegel, \& Smith, 1997) and White privilege (Pulido, 2000).

A political economic perspective is not the only lens through which access to public open space can be explored. A theory rooted in the historical processes of suburbanization and decentralization may also offer some guidance. Given that urbanization is a process of population concentration that occurs through both a "multiplication of points of concentration and [an] increase in the size of individual concentrations" (Tisdale, 1942, p. 311), a secondary 
proposition to explain individuals' access to public open space can be developed. This second proposition adapts Christaller's central place theory (1933) and posits that access to open space is determined by the simple fact that as cities develop, the urban core develops first, followed by moderately dense areas that eventually extend out into rural and undeveloped areas.

To empirically test these hypotheses, we examine Raleigh, North Carolina as a case study. Using data on the spatial location and concentration densities of the area's urban minorities as well as the existing locations of public open space, a series of analyses are employed to answer two central questions: first, are public open space being utilized as a mechanism of marginalization, resulting in racial and ethnic minorities having less access to the benefits provided by public open spaces? Second, is access to open space determined by the spatial patterns of the metropolitan areas' minority population (the growth machine theory), or is open space determined by the historical processes of suburbanization and decentralization (central place theory)? The results reveal that while both theories may be valid at certain spatial scales and in certain social contexts, neither, when considered in isolation, can provide a sufficient framework for understanding the social causes and consequences of urban open space planning and development.

\section{Need for socio-spatial explorations of urban open space access}

Empirical examinations of the relationships between minority populations and access to public open space are particularly needed as many progressive urban planners and policy makers are attempting to recast urban open spaces as spaces which express personal and cultural diversity (Ward Thompson, 2002). Ward Thompson (1996) notes the role of public open space in American life has dramatically shifted during the last several decades. She notes park and green space planning often assumed public open spaces exemplified the ideals of social and cultural "melting pots" and largely ignored cultural differences. More recently, however, many urban planners and management frameworks have attempted "to accept diversity in needs, attitudes and expression” (Ward Thompson, 2002, p. 60).

Particular emphasis on the spatial dimension of these relationships is warranted given that numerous studies have illustrated urban open space usage is dominated by individuals and groups who live in immediate proximity to the resource (e.g., Comedia/Demos, 1995; Godbey, Graefe, \& James, 1992; Kaplan \& Kaplan, 1989). As a result, the social groups with most need for access to public open space and the benefits that urban green spaces can provide are those groups who are least mobile-the elderly, the poor, those without personal transportation, and in particular importance to this study, socially marginalized groups like racial and ethnic minorities. A large body of past research has recognized this need and has attempted to discern if, and to what extent, minority groups are marginalized from urban open space (e.g., Heynen, 2006; Heynen, Perkins, \& Roy, 2006; Powell, Slater, \& Chaloupka, 2004; Wen, Zhang, Harris, Holt, \& Croft, 2013; Wolch, Wilson, \& Fehrenbach, 2005). While notable, this research has yet to employ a spatially-explicit analytical approach that can be utilized to discern exactly where specific minority groups are experiencing marginalized levels of access within an urban area.

To fulfill this need, we present two rival hypotheses to explain access to parks, greenways, and natural areas. We frame the research with the following questions: is there inequitable access to open space? And if so, does it occur along racial lines? If not, can access to open space be predicted by some broader determinant inherent in the realities of urban growth?

\section{Related literature}

\section{The city as a growth machine}

Urban space is understood to be socially and economically valued land. In their influential thesis on the political economy of urban space, Logan (1976) and Molotch (1976), and later Logan and Molotch (2007) suggest that urban growth is predominantly driven by a land-based elite who's primary concern is maximizing exchange values through the process of land-use intensification. Urban space is a finite resource that is utilized by individual actors to generate what Marx would refer to as surplus value. To focus on local political economies, land parcels must be conceived "not merely as a demarcation of legal, political, or topographical features, but as a mosaic of competing land interests capable of strategic coalition and action" (Molotch, 1976, p. 311).

The key assertion behind Logan and Molotch's thesis is that otherwise disparate local actors and organizations coalesce to form "growth machines" designed to direct resources into specific urban locations and stimulate growth. The collective interest of a growth machine lies in maximizing the urban rents which its constituents have a vested interest in, most explicitly through direct ownership. Those actors and organizations involved in a growth machine, the land-based elites, primarily pursue exchange values, the monetary returns that can be obtained from the exchange of pieces of property. The motivations of a growth machine-maximizing exchange values-are inherently contradictory to individuals, particularly residents, whose primary concern is maintaining use values. Use values being the personal and social utility a piece of property generates by meeting individuals' non-economic wants and needs in their daily lives (Harvey, 2006).

Through the Marxian notions of exchange and use values, the growth machine hypothesis ties power and social class hierarchy to actual physical space. The conflict between those seeking to gain from exchange values and those from use values is highly asymmetrical. Each group of individual actors is differently equipped to mobilize their individual, organizational, and class resources to meet their collective needs.

Because of the asymmetrical power relationships tied to place, the life chances of poor and minority neighborhoods are dramatically impacted. Local residents who live in poor and minority communities do not have an equitable say in local decision making, but they do pay the price for others' plans-they suffer a double disadvantage (Logan \& Molotch, 2007). This consequence of growth machines can be seen in the consistent and positive relationship found between 
rates of urban economic growth and income inequality (e.g., Bhatta, 2001; Korpi, 2008; Moller, Alderson, \& Nielsen, 2009). The life chances of individuals who live in poor and minority neighborhoods are directly influenced by their ability to access and utilize public open space, a fact highly dependent upon the actions of local growth machines. This point can be further expounded by looking specifically at the role of public open spaces-parks, green ways, and natural areas-in urban growth.

\section{Public open space and the growth machine}

Neoclassical theories of economic agglomeration largely ignore the presence or role of public open space in urban areas. The spatial composition of the city is understood as a product of individuals and firms seeking to maximize exchange values; as a result, it is entirely logical to anticipate public open space to be spatially and economically marginalized. As a publicly held good, it has no exchange value for any individual or organization. Public open space stands in the way of production efficiencies that can be gained from increased economic agglomeration and urban density. The neoclassical theories of growth conceptually fit the dominant mode of manufacturing production of the early 1900s. The applicability of neoclassical economic theory has increasingly been called into question by scholars like Logan and Molotch (2007) who conceptualize growth as a product of political and economic forces, and others who emphasize the influence of telecommunications and globalization on urban spatial structure (e.g., Clark, 2000; Sassen, 2001).

Logan and Molotch's growth machine hypothesis suggests that urban public spaces-whether they are open spaces, museums, or theaters-play a critical role in urban growth as they are able to stimulate financial activity. The local landed elite leverages both political and economic advantages to maintain power and control over urban growth and development. Control over urban development patterns encompasses both built and natural spaces, as well as the provision of services to maintain them. Regarding urban open space in particular, the local landed elite promotes and encourages the designation and maintenance of these spaces as they attract mobile capital, give individuals a reason, aside from work, to visit the area and entice firms and potential employees who desire an opportunity to both play and work in close proximity to their home.

\section{Political mechanisms}

Under the growth machine hypothesis, the provision of urban open space is unevenly distributed, with neighborhoods capable of supporting local planning boards' political coalitions receiving a disproportionate amount of benefits. Koehler and Wrightson (1987) explicitly examined this proposition in their study of the provision of Chicago parks between the 1960s and 1980s. Their analysis revealed neighborhoods largely composed of a single minority group (>80\%) had significantly less access to park facilities when compared to more heterogeneous neighborhoods. The authors conclude, "equity is at most a minor consideration in Park District decision making” (1987, p. 93). This finding ran counter to the dominant mode of thinking at the time, which suggested the delivery of urban services was primarily a function of bureaucratic norms, and consequently, tended to be equitably distributed (e.g., Mladenka, 1980).

Despite these early inroads, which suggested race does play a role in urban planning decisions, contemporary scholars note urban environmental justice research often avoids a direct and substantive discussion on racism (Pulid0,2000 ). As a product of historical and cultural processes, as well as the objective realities of any democratic system, racial minority groups have less access to political and economic power in urban social hierarchies. Consequently, racial minorities by in large, tend to have less access to the decision space in which key issues, mainly pertaining to the distribution of public goods and services, are decided upon. The under-representation of racial minorities in the processes of local governance tends, as expected, to result in political economic decisions that favor the over-represented majority, thus leaving minority populations to face the consequences of decreased access to public services. This process is a manifestation of White privilege, the hegemonic structures, practices, and ideologies that reproduce Whites' privileged status (McIntosh, 2004; Pulido, 2000). "White's do not necessarily intend to hurt people of color, but because of they are unaware of their white-skin privilege, and because they accrue social and economic benefits by maintaining the status quo, they inevitably do." (Pulido, 2000 , p. 15). The outcomes of White privilege has been extolled in studies of racial minorities' access to medical services (Mayberry, Mili, \& Ofili, 2000) and credit/insurance (Squires, 2003), as well as their role in decisions on where to cite local industrial facilities (Bullard, 2000; Pastor, Sadd, \& Hipp, 2001).

\section{Economic mechanisms}

Under the growth machine hypothesis, the uneven distribution of urban open space is driven by economic as well as political forces. Recently, a number of urban scholars (e.g., Clark, Lloyd, Wong, \& Jain, 2002; Florida, 2002; Glaeser \& Rappaport, 2001) have pointed out how the need and desire for urban public open spaces has rapidly increased as a result of the shift from a manufacturing based economy to one driven by technology and innovation. The rise of the information economy, accompanied by a more educated and mobile workforce has led many to question whether unfettered development is actually the best fuel for the growth machine. "Smart" or "managed growth" strategies may actually boost exchange values relative to alternative traditional production-based planning, as they attract the most rapidly growing firms and individuals. "The information city implies the city of leisure" (Clark et al., 2002, p. 497). As a result, in many cities the growth machine may have given way to the entertainment machine (Clark \& Lloyd, 2000).

This recent trend in economic development can have direct consequences for racial minorities' access to public open space; this primarily occurs through the transformation of local real-estate markets. The presence of public open spaces can and often does have positive effects on local real property values (e.g., Tajima, 2003). Individuals and firms bid up the prices of properties located proximate to open spaces precisely because of the perceived benefits they can provide. However, due to the fact racial and ethnic 
minorities, on average, have lower incomes than whites (Moller et al., 2009), their ability to purchase housing near public open space is reduced. Gentrification efforts, which often include the development of new public open space, can also result in racialized access given they tend to occur in areas where racially marginalized homeowners are currently concentrated (Glick, 2008). Other economic forms of racism occur through discriminatory policies in obtaining property insurance (Squires, 2003) and mortgages (Stuart, 2003).

\section{Previous empirical work}

The political and economic mechanisms of Logan and Molotch's growth machine theory are explicitly tied to spatial patterns of urban land use (Heynen \& Perkins, 2005). The work of several scholars focused on the historical transformation of urban infrastructure has empirically illustrated this proposition. Examining changes in urban forest canopy cover (a proxy for urban open space) in relation to median household income levels within the US city of Indianapolis, Heynen (2006) found that as income levels of urban residents increased the proportion of forest cover decreased. Heynen contends this trend is a product of capitalism's attempt to maximize both production and consumption, which results in the inevitable conversion of urban open space. In a second study, this one focused on the US city of Milwaukee, Heynen et al. (2006) expanded upon his findings by demonstrating the metabolism of urban open space had differential impact on different racial groups. African-Americans and Hispanics had less forest canopy cover in their neighborhoods. Again, Heynen argues the uneven presence of forest cover is an outgrowth of the urban political economy being controlled by the White majority.

Other recent research, less grounded in theories of political economy, has also found evidence for the uneven distribution of open space relative to neighborhoods' racial composition. Wolch et al. (2005) focused exclusively on park access in Los Angeles and found that Census tracts dominated by Black and Latino populations had less access relative to tracts with a White majority. Similar findings of marginalized access were found in a study of four Maryland counties (Abercrombie et al., 2008). More generalizable studies focused on either large samples of US Cities (Powell et al., 2004) or the entire nation (Wen et al., 2013), have also yielded similar results.

Recent empirical work also illustrates uneven access to urban green space occurs not just along racial lines, but along social and economic lines (e.g., education and income levels) as well (Hope et al., 2003; Iverson \& Cook, 2000; Kendal, Williams, \& Williams, 2012; Lubbe, Siebert, \& Cilliers, 2010; Mennis, 2006; Talarchek, 1990). Minority groups can suffer exacerbated levels of marginalization and degraded welfare if they are minorities in more than one socio-economic category. For example, Brownlow (2006a, 2006b) showed how women of color were especially vulnerable to physical attacks in Philadelphia's Fairmont Park as a result of poor park maintenance and management. The case reveals another layer of the growth machine theory by suggesting that even when parks and greenspaces are available in minority neighborhoods, city officials underinvest in their maintenance and management (Byrne, 2012; Madge, 1997; Whitzman, 2002).

The social consequences of urban growth, particularly the manufactured disadvantages that occur along social and economic lines, can easily go unnoticed. These consequences are not overt in the growth machine, rather they are systemic to urban growth itself. The benefits of growth accrue to those actors with the political and economic power. When these actors do not represent racial minorities, spatial disparities in access to public goods and services emerge. However, racism manifested through urban growth machines is not the only potential explanation for differentiated access to public open space. An alternative hypothesis arises when we acknowledge the availability of open space access is, at least partially, a product of the historical processes of suburbanization and decentralization. That is, as urban centers grow through the agglomeration of economies, open space itself gets eroded by new firms and new development strategies that cite themselves near the urban core. What open space is left remains near the urban periphery and, as a result, access can be explained by individuals' position in the urban spatial hierarchy. This hypothesis is grounded in neoclassical models of growth and can best be described as an extension of central place theory.

\section{Central place theory}

Numerous theories, conceptualizations, and diagrams have been developed in attempts to describe and predict the growth of urban areas. For example, Howard's garden city models were some of the earliest endeavors to develop a systematic planning and development process that incorporated public open spaces (Hall, 1998; Howard, 1898). Much of the preliminary research on urban growth was grounded in spatial economics and economic geography and focused primarily on the agglomeration of economic activities (e.g., Isard, 1956; Weber, 1909). Central place theory, which was initially developed by Christaller (Bird, 1977; Christaller, 1933) and later refined by Lösch (1941) has been central to much of the urban geography, economics, and sociology literatures (e.g., Berry \& Parr, 1988; King, 1984; Mulligan, 1984; Ullman, 1941). The theory is currently experiencing what has been referred to by some as a "reemergence" given its ability to easily compliment other, more recent, theories within urban economic geography (Mulligan, Partridge, \& Carruthers, 2012). For Christaller, central place theory explained the tendency of settlement patterns to be organized in a cascading spatial hierarchy. The hierarchy is conceptualized around a continuum of goods and services that are produced within an urban area. The core central place within an urban landscape is believed to have exhaustive economic production capabilities (i.e., it is capable of producing all of the goods and services to meet local demand). Secondary areas, located along the periphery of the core, produce some, but not all, of the goods and services required by local demand. These secondary central places, consequently, exert demand pressures on the most central location for those goods and services they are unable to produce. This interlocking spatial hierarchy continues to cascade outward. What emerges from this process is an urban spatial hierar- 
chy with a central urban core supplemented by several peripheral cores. Recent empirical work has demonstrated the cascading spatial hierarchy formed within central place theory is the most optimally efficient organizational pattern for serving a dispersed population (Hsu, 2012).

Historically, spatial hierarchies emerged as manufacturing industries accumulated in core nodes that both facilitated access to markets and eased distribution to agricultural hinterlands. Cronon (1991) illustrates this point through his historical account of how Chicago became a central hub in America despite its relative lack of any environmental advantages-what Cronon referred to as "first nature". Cronon notes that Chicago grew as an urban center because of its "second nature"-its vital role as a national transportation hub. Initially sparked by its competitive advantage in transportation, Chicago's population grew, as did its potential to attract a wide and diverse set of economic sectors. The self-reinforcing process of economic aggregation and population growth, which is a fundamental assumption of central place theory, is a driving force behind the growth of nearly all urban areas (Mulligan et al., 2012).

Recently, central place theory has played a central role in the emergence of a new economic geography and new theories of urban growth (McCann \& Van Oort, 2009). Particularly, the work of Krugman (1991) and Porter (1998) has conceptualized urban growth, explicitly the spatial concentration of production and labor, as a natural consequence of market interactions involving economies of scale at the level of the individual firm. Krugman (1993) notes that market potential is driven by the fact firms have an incentive to concentrate production in a limited number of locations. Firms choose locations with good access to markets and simultaneously attempt to cluster in order to realize mutual advantages (e.g., transportation costs are reduced between competing firms the more proximately located they are). Concurrently, consumers attempt to minimize costs in procuring goods and services by residing near spaces where those goods and services are provided (Golledge \& Stimson, 1997; Rushton, 1969). The result of these dual-processes is an autocatalytic process of population concentration and the expansion of market potential, ultimately forming patterns of urban land use. The results generated by these new theories of growth are reminiscent of Christaller's conceptualization of a spatial urban hierarchy.

Explicit in more recent models of urban growth as well as the in the earliest formulations of central place theory is the process of urbanization that results from the growth of existing core areas, and the emergence of other peripheral cores. Tisdale presents this process elegantly by noting:

urbanization is a process of population concentration. It proceeds in two ways: the multiplication of points of concentration and the increase in size of individual concentrations. It may occasionally or in some areas stop or actually recede, but the tendency is inherent in society for it to proceed until it is inhibited by adverse conditions. (1942, p. 311).

Public open space can play various functional roles in the process of urbanization. If one focuses primarily on economic production, accepting that economic agglomeration is the central driver of urban growth, public open spaces could be seen as constraints on production. The existence of open space increases transportation costs and thus works counter to the goals of individual firms. After all, without the existence of scale economies in production, economic activity would be spatially distributed equally (Fujita, Krugman, \& Venebles, 1999; Fujita \& Thisse, 2002). However, in consumption terms, the existence of public goods like open space may actually be beneficial to economic production. As Florida (2002) notes, the urban amenities within cities can both draw creative, talented, and highly educated employment to the area and serve as a social externality that actually boosts individuals and organizational economic productivity. Florida claims that urban planners and policy makers, if they want to grow economically, need to invest in developing urban settings that both attract and facilitate the needs of the professional, scientific, and technical communities that facilitate economic growth.

Whether urban planners and policy makers focus on economic production or the development of urban amenities has direct influence on the spatial composition of access to public open space. If economic production is made paramount, public open spaces are likely to get consumed by the process of urbanization and growth. What public open spaces do exist will be marginalized to the periphery of the urban spatial hierarchy. However, if amenity development is a principal concern of decision makers, public open spaces will remain available in the urban core. In the analysis to follow, we empirically test whether individuals' access to public open space is determined by their relative location in the urban spatial hierarchy. If individuals' located further from the urban core have relatively more access to public open space, it implies urban growth has left little room for public space in the urban core. However, if individuals' located nearer the city center have relatively more access to public open space, then parks and green spaces are being provided for as an amenity to urban residents. In the analysis to follow, we explore these hypotheses in conjunction with the marginalized access hypotheses derived from the growth machine theory. When presented together, they can offer a more comprehensive view of metropolitan residents' access to public open space.

\section{Methodology}

\section{Spatial approach}

The study of race/ethnicity and public open space has been studied from numerous disciplines. Leisure science, with its roots in management and public administration, has addressed the topic fairly extensively (Floyd, Bocarro, \& Thompson, 2008; Shinew et al., 2006). Scholars in human geography have also seriously addressed the issue from numerous perspectives such as the social construction and cultural representation of park spaces (Katz \& Kirby, 1991; Willems-Braun, 1997) to more historical and politically oriented approaches (e.g., Byrne, Kendrick, \& Sroaf, 2007). Recently, numerous scholars have called for a socio-spatial explorations of park access and use (Byrne \& Wolch, 2009; Noe \& Snow, 1989; Tierney, Dahl, \& Chavez, 
2001). Our research contributes to this body of knowledge on both empirical and theoretical fronts.

\section{Data and variable selection}

For this study, the unit of analyses is the US Census block, the smallest geographic unit used by the US Census Bureau. Data came from geographic information systems (GIS) databases managed by the US Census Bureau and Wake County, North Carolina. Given the purpose of this research is to examine differentiated access to public open space across racial lines, block level shape files were obtained from the US Census Bureau. These files contain socio-demographic data collected from the 2000 US Census aggregated at the level of the Census block. ${ }^{2}$ Variables of interest for this study include the proportion of each Census block's total population that identified with a single racial or ethnic group on the 2000 US Census. Particularly, we focus on those individuals who identified themselves as White, Black, Asian, or Hispanic.

To test the central place hypotheses noted above, data were also generated to measure individuals' position in the spatial hierarchy. This measure was calculated from the centroid of each Census block to the center of Raleigh's core business district. The distance of Census blocks, neighborhoods, or households to a city's core business district is a frequent measure of urban spatial position; it is most frequently utilized in hedonic models of economic goods (e.g., Lee, Taylor, \& Hong, 2008; Ryan \& Weber, 2007).

A second set of data files were obtained from Wake County, which maintains detailed geographic information data of land use within its boundaries. The GIS data layers include areas defined as public open space; this includes parks, natural areas, greenways, and open space owned by the State. ${ }^{3}$ We excluded from the analysis other public open spaces such as schools, environmental mitigation areas, and gameland given the unique functions and outcomes these areas serve. The dependent variable is the proportion of each Census block designated as a park, natural area, greenway or state-owned open space.

\section{Spatial heterogeneity}

The first realization that must be made in a socio-spatial exploration of park access is that neither public open space nor urban racial/ethnic populations are randomly spatially distributed. For example, the spatial pattern of racial/ethnic compositions and public open space are shown in Figs. 1 and 2 . The significant clusters of green space access are presented in Fig. 3. The clusters were determined by estimating local indicators of spatial autocorrelation, which determines spatially defined patterns of heterogeneity (Anselin, 1988). Red areas designated as "high-high" are

\footnotetext{
${ }^{2}$ The 2000 US Census data was chosen because we wanted data at the most acute spatial scale possible (the US Census block) given our geographically bounded study area. The 2010 Census data on socioeconomic characteristics of individuals Census blocks had yet to be released at the time of analysis.

${ }^{3}$ Within North Carolina, these areas are managed as a part of the state university system; they contain trails and recreational opportunities available to the public. State-owned land designated as open space also facilitates many of the same public goods provided by other areas (i.e., many of the area's greenways run through stateowned public land). Even though designation may be different, the land areas are functionally similar.
}

Census blocks with a high degree of public open space surrounded by other Census blocks with high levels of public open spaces. Blue, "low-low", areas are Census blocks with relatively low amounts of public open space surrounded by other blocks with low amounts of public open space. The "low-high" and "high-low" categories follow accordingly.

With regard to public open space, spatial heterogeneity arises because of either unique geographic features that make particular tracts of land amenable to open space conservation or historical events and planning ordinances that have a large influence on what places get set aside for public use. Given this realization, standard investigative techniques that analyze a sample of either people or spaces as randomly distributed are inappropriate. A more proper and informative analytical approach should take into account spatial heterogeneity. For example, findings that would normally be acceptable with respect to the role of key variables (e.g., neighborhood racial composition) and access to open space obtained from the results of global estimates (e.g., OLS regressions) may actually mask significant local variations in access. The standard estimates may suggest no relationship between racial composition and open space for the entire metropolitan region. However, race may be significantly and positively related to open space access in some neighborhoods while simultaneously being significantly and negatively related to open space access in others. As a result, the average net effect from standard estimation procedures would be insignificant, resulting in both an ignorance of the true nature of the relationship, and potentially misguided public policy.

\section{Model specification}

Given the potential fallacies of estimation procedures aimed at providing global coefficient estimates, we first calculate these estimates and then compare them with an alternative analytical approach-a geographically weighted regression-that more appropriately accounts for spatial heterogeneity. Two global estimation procedures are calculated. The first estimation procedure is a standard Tobit regression and the second is a Spatial Error Model (SEM) (Anselin, 1988). The Tobit model is truncated at zero given the large proportion of Census blocks with no public open space. The SEM model is specified as:

$$
\begin{aligned}
& y_{i}=\beta_{0}+\beta_{1} x_{i 1}+\beta_{2} x_{i 2}+\ldots+\beta_{k} x_{i k}+u, \\
& u=\rho W u+\varepsilon, \varepsilon \sim N\left(0, \sigma^{2} \mathbf{I}_{n}\right), i=1, \quad 2, \ldots, n,
\end{aligned}
$$

where $\rho$ is the spatial autocorrelation parameter and $W$ is the spatial weight matrix created from the inverse squared distances between points. The SEM model assumes that for more proximate Census blocks, there is a correlation in regression residuals.

Subsequent to the Tobit and SEM estimations, Geographically Weighed Regression (GWR) (Fotheringham, Brunsdon, \& Charlton, 2002) was utilized to estimate separate coefficients for each observation. The process of estimating a regression equation for each Census block allows spatial relationships to vary from one neighborhood to the next. In each regression equation, the influence of independent variables differs relative to the influence observed in proximate blocks. More succinctly, coefficients 

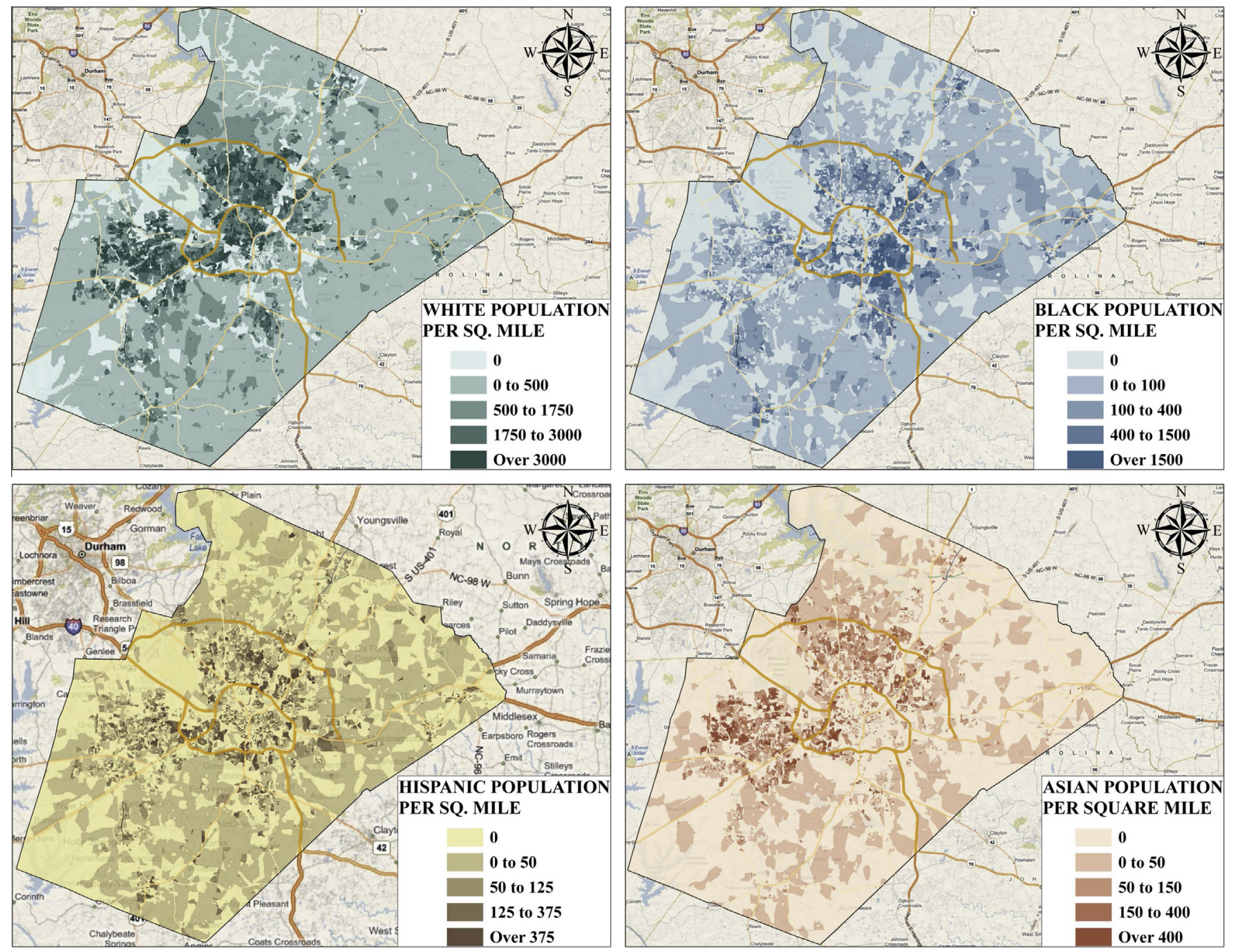

Fig. 1. Spatial composition of racial densities in Wake County, North Carolina.
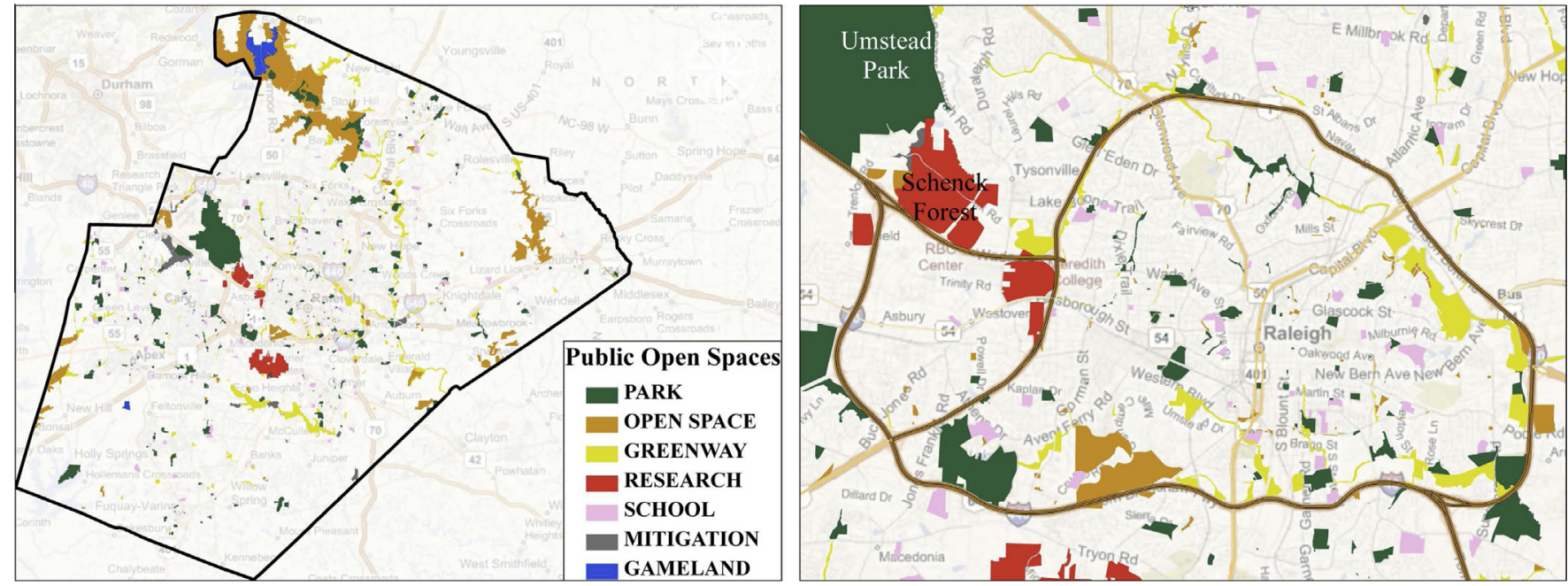

Fig. 2. Spatial pattern of public open space for Wake County and the Core of Raleigh, North Carolina. 


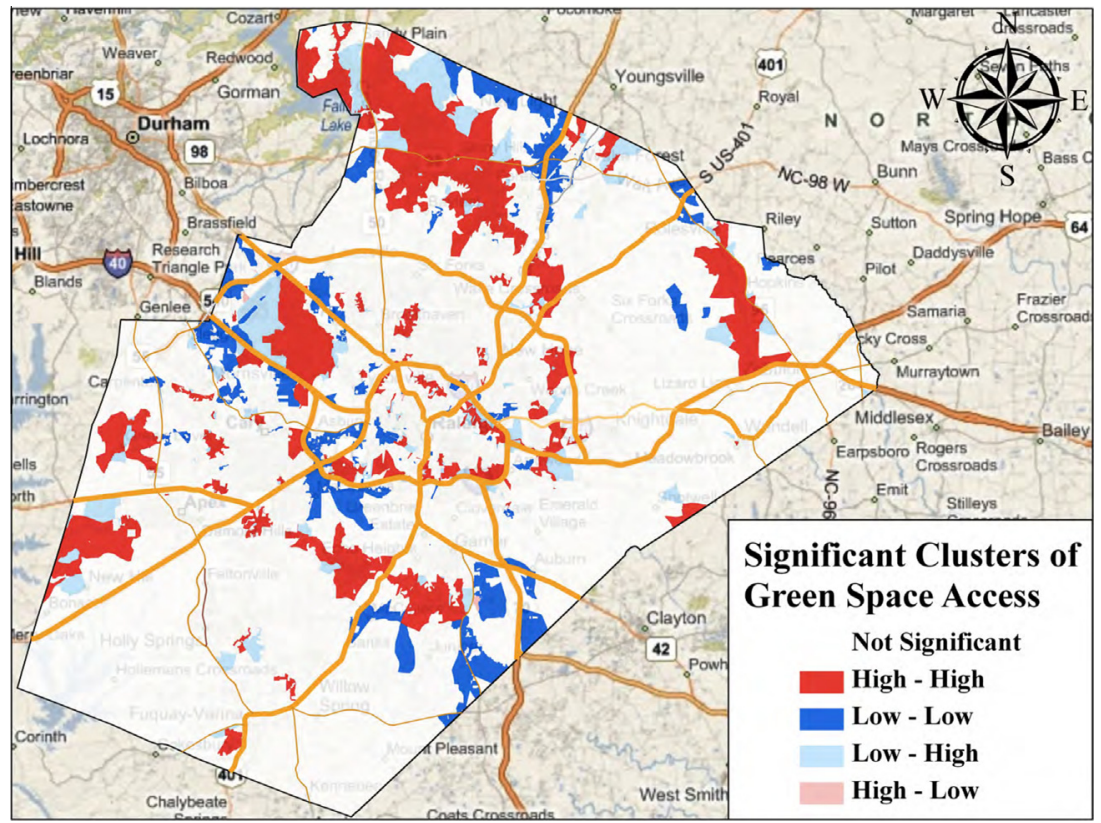

Fig. 3. Significant clusters of open space access (local indicators of spatial autocorrelation).

are weighted by their spatial proximity. This spatial weighting follows the assumption that more proximate locations are more alike and therefore smoothes parameter estimates allowing the researcher to see neighborhood level differences in access to public open space.

Each regression in a GWR model is specified as:

$y_{i}=\beta_{i 0}+\beta_{i 1} x_{i 1}+\beta_{i 2} x_{i 2}+\ldots+\beta_{i k} x_{i k}+\varepsilon_{i}$;

$\varepsilon_{i} \sim N\left(0, \sigma^{2}\right), \quad i=1,2, \ldots, n$,

where the subscript $i$ indicates there is a separate set of $(k+1)$ parameters for each of the $n$ observations. In this study, $n=$ the number of Census blocks in Wake County. The parameter estimates of each regression in a GWR are given by:

$\beta_{\hat{i}}=\left(X^{\prime} \mathbf{W i X}\right)^{-1} X^{\prime} \mathbf{W i Y} ; \quad i=1,2, \ldots, n$,

where Wi is the $n \times n$ weight matrix whose off-diagonal elements are the weights of each observation relative to $i$, that is, $\mathbf{W i}=\operatorname{diag}\left(w_{i 1}, w_{i 2}, \ldots, w_{i n}\right)$.

To more explicitly outline these analyses, the models can be generalized and denoted as:

$$
\begin{aligned}
\% \text { OPEN_SPACE }= & \alpha_{i}+\delta_{i} \% \text { WHITE }_{i 0}+ \\
& \gamma_{i} \% \text { BLACK }_{i 0}+ \\
& \theta_{i} \text { ASIAN }_{i 0}+ \\
& \Psi_{i} \text { HISPANIC }_{i 0}+ \\
& \varphi_{i} \text { DIST }_{i j}+\varepsilon_{j},
\end{aligned}
$$

where $i=1,2, \ldots, n$, and $n$ is the number of Census blocks in Wake County.

In addition to GWRs value of providing an estimation procedure where local variations can be calculated and then visually illustrated, the results can also inform subsequent global approaches. If similar patterns of local effects are noticed (i.e., heterogeneity exists, but coefficient direction is consistent), increased confidence may be placed in subsequent analysis that cannot be modeled with spatial methods due factors such as excessive multicollinearity, which often hinder the inclusion of all desired variables in spatial models. This point will be particularly important in the testing of the central place theory hypotheses.

\section{Results and discussion}

\section{Model comparison}

The results from the Tobit, SEM, and GWR regressions are shown in Table 1. For both the Tobit and the SEM regressions, asterisks indicate parameter significance. For the GWR model, all of the independent variables' GWR coefficients exhibited statistically significant spatial variation at the .001 level across the county. Significant spatial variation was determined by the Monte Carlo test described by Fotheringham et al. (2002).

The general assumption of significant spatial variation in regression coefficients was supported, as the Global Moran's I test of spatial autocorrelation on the GWR residuals was high (0.41). Further evidence of the need for a spatial model can be seen through the significant test for spatial error dependence reported from the SEM regression and the large improvement in adjusted $R^{2}$ values-from 0.03 with the Tobit regression to 0.16 with the GWR.

While there are no differences in the direction or significance of the independent variables between the Tobit and the SEM, it is clear that the Tobit model, with its inflated standard errors, is consistently over exaggerating the relationship between the predictors and the proportion of each Census block designated as public open space. A visual analysis of the large variations in GWR coefficients reveal that global approaches such as the Tobit and the SEM can mask heterogeneity in statistical relationships observed across space. For example, the SEM suggests that after controlling for the other factors in the model, as the proportion 
Table 1

Results from tobit, spatial error, and geographically weighted regressions.

\begin{tabular}{|c|c|c|c|c|c|c|c|c|c|}
\hline & \multicolumn{2}{|c|}{ Tobit regression } & \multicolumn{3}{|c|}{ Spatial error regression } & \multicolumn{4}{|c|}{ Geographically weighted regression } \\
\hline & Coef. & Std. error & Coef. & Std. error & Min. & Lower quartile & Median & Upper quartile & Max. \\
\hline WHITE_PROP & $-0.25^{* * *}$ & 0.03 & $-0.07^{* * *}$ & 0.00 & -0.57 & -0.08 & -0.05 & -0.03 & 0.04 \\
\hline BLACK_PROP & $-0.20^{* * *}$ & 0.05 & $-0.07^{* * *}$ & 0.01 & -0.70 & -0.07 & -0.05 & -0.02 & 0.07 \\
\hline ASIAN_PROP & -0.24 & 0.22 & -0.05 & 0.03 & -1.87 & -0.13 & -0.06 & -0.03 & 0.51 \\
\hline HISP_PROP & 0.11 & 0.12 & -0.03 & 0.02 & -0.99 & -0.06 & -0.03 & 0.01 & 0.24 \\
\hline NEAR_DIST & $-9.05 \mathrm{e}^{-6^{* * *}}$ & 0.00 & $-6.31 \mathrm{e}^{-7^{* *}}$ & 0.00 & 0.00 & 0.00 & 0.00 & 0.00 & 0.00 \\
\hline AREA_SQMILE & $0.68^{* * *}$ & 0.04 & $0.07^{* * *}$ & 0.01 & -0.02 & 0.05 & 0.12 & 0.27 & 1.50 \\
\hline Constant & $-0.44^{* * *}$ & 0.03 & $0.09^{* * *}$ & 0.00 & -0.18 & 0.05 & 0.07 & 0.11 & 0.67 \\
\hline \multicolumn{10}{|l|}{ Summary statistics } \\
\hline Sigma & 0.78 & 0.01 & & & & & & & \\
\hline Lambda & & & $0.24^{* * *}$ & 0.01 & & & & & \\
\hline Spatial error dependence & & & $271.47^{* * *}$ & & & & & & \\
\hline Adjusted $R^{2}$ & 0.3 & & 0.7 & & & & 0.16 & & \\
\hline AIC & 11185.66 & & 8003.49 & & & & 8837.63 & & \\
\hline
\end{tabular}

$p \leq 0.05$

$p \leq 0.01$

$p \leq 0.001$

of a Census block's Black population increases by $1 \%$, its proportion of public open space decreases by $7 \%$. However, when the spatial variability of the area's racial composition and access to public open space are taken into account, it becomes clear that some predominantly Black neighborhoods are faring much worse (the minimum coefficient for a single Census block was -0.70). The model comparison illustrated in Table 1 shows the need to consider the heterogeneous nature of social phenomenon and relationships observed in urban areas. The comparison also illustrates the need for policy efforts to be focused at specific urban areas and neighborhoods as opposed to blanket regional or county-wide efforts.

\section{Marginalized access?}

Turning to the specific hypothesis posed earlier, we set out to understand if public open space was being utilized as a mechanism of marginalization, resulting in racial and ethnic minorities having less access to the benefits provided by public open spaces. The results of the SEM regression reveal this is only true for Black neighborhoods and not for the either Asians or Hispanics. The large variation in the BLACK_PROP regression coefficients calculated through the geographically weighted regressions indicates that even among Black communities, access to public open space varies widely. This large variation can be seen in Fig. 4 (Quadrant 2). The illustration plots the regression coefficients relative to their median value (which in this case is -0.05). Red values indicate areas of the county where a greater than average negative relationship is seen between the Black population and access to public open space. Likewise, blue values indicate areas were a greater than average positive relationship exists between Black individuals and access to public open space. Despite the large variation, very few predominantly Black Census blocks were the site of a positive relationship between Black individuals and public open space (the maximum coefficient for any one block was just 0.07 ).

While access to public open space was not significantly related to either of the other minority groups, there were still large variations within these groups relative to their access to open space access. Again these variations can be seen in Fig. 4 (Quadrants 3 and 4). Noticeable is the dramatically different patterns between each of the minority groups and where their levels of access are highest. In a visual comparison of Quadrants 3 and 4 of Fig. 4, you can see a large portion of central western Wake County where the Hispanic population's access to public open space is concentrated and below average. In the same area, the Asian population has an average level of access. However, greater concentrations of Asian individuals in the north and central portion of the county are consistently related to above average levels of marginalization from public open space (Quadrant 4). Contrast this same area with the illustration of the Hispanic populations' regression coefficients and we can see average or positive levels of access.

The growth machine hypothesis suggests that marginalized access to public open space should be consistent and occur along racial lines. However, the data from our study area in Raleigh illustrate this is not the case-marginalized access to public open space did not occur for all the racial and ethnic groups considered. Furthermore, the results reveal that as concentrations of the White population increase, their access to public open space decreases. On average across the entire county, the coefficients are nearly identical for both whites and blacks.

These findings certainly do not disprove the growth machine hypothesis or suggest that racism does not exist with regard to individuals' residential choices and their access to public services. What these findings do illustrate however, is that the urban spatial structure, and the racial composition of its inhabitants, is dynamic and highly variable. It is no longer tenable to simply acknowledge that certain social groups are marginalized from public services and urban amenities. Which groups are marginalized and where that marginalization is occurring is the question that needs to be asked. The growth machines still exist, and as Logan and Molotch initially noted, they act in pluralistic collaborations to bend and shape the life chances of local individuals. They determine who, in material terms, gets what, and where. With regard to public open space, that "where" may be much more fragmented and differentiated across minority groups that previously thought. 

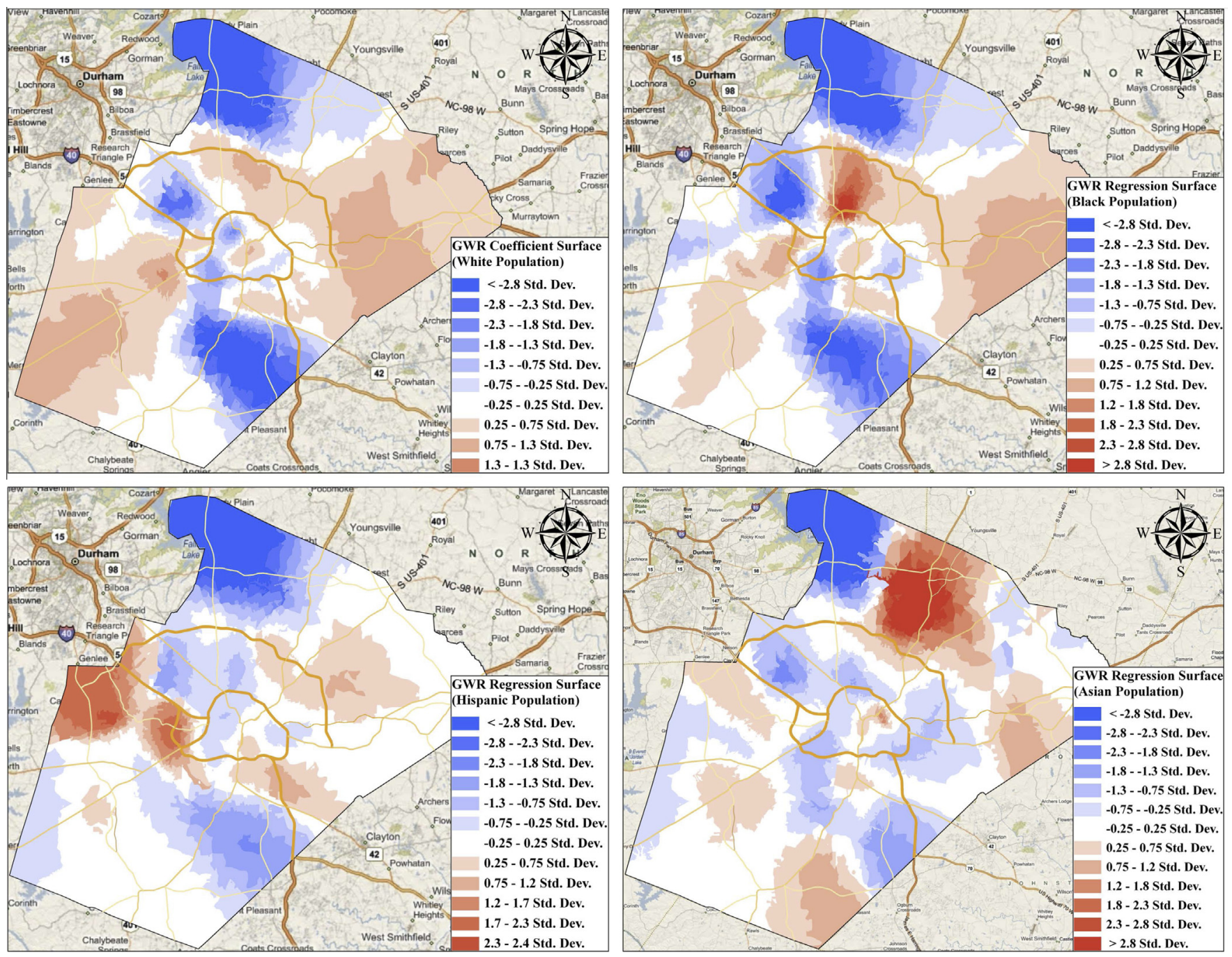

Fig. 4. Spatial patterns of geographically weighted regression coefficients.

\section{The role of central place}

We also set out to determine if access to open space is determined by the dominant historical processes of suburbanization and decentralization. The hypothesis presented would suggest that as urbanization occurs-as firms look to agglomerate and realize mutual rewards for clustering-public open space more proximate to the urban core would be sacrificed to development. As a result a positive relationship would be noticed between an areas' distance from the urban core and the proportion of its land designated as parks, greenways or natural areas. The results from Raleigh however, do not support this theory. Rather for both the basic Tobit regression model and the SEM regression, a significant and negative relationship was noticed between distance from the urban core and available public open space. These findings could suggest, as Clark and Lloyd (2000), Florida (2002) and Glaeser (2000) have, that urban-proximate public open space is a highly valued resource that is being conserved against urban development. The spatial hierarchy of the metropolis exists, and individuals' location in it influences their access to public open space. The direction of that influence however, is not consistent with the models of urban growth that solely stress exchange values. Rather, the functional use values placed upon urban public spaces (either as a means to provide benefits to nearby residents, or as mechanism to attract mobile firms and individuals) has firmly embedded them in spaces more proximate to the urban core.

\section{Conclusion}

The benefits of public open spaces to local residents (use values) and the political and economic elites (exchange values) are well known. In this research, we set out to better understand how the conflict between use and exchange manifested itself through racial and ethnic minorities' access to public open space. Decades of literature and data support the fact that there are social consequences to urban growth. These consequences can take many forms, form fueling already large income inequalities to exacerbating existing social cleavages. Understanding spatially-explicit disparities in individuals' access to public open space, however, has largely gone unexplored. As a result of urban growth leading to uneven racial compositions and the 
heterogeneous patterns of public open space, interesting patterns of race and place have emerged. The results of the analysis conducted here illustrate that access is not defined along racial lines, but different racial groups have differentiated access in different areas of the city. The unique racialized patterns of access illustrate the spatial consequences of growth; they also form a focused policy instrument that can be utilized to target specific groups in particularly marginalized spaces.

The growth machine hypothesis and central place theory can each operate within certain social and economic contexts. The results of this case study reveal that neither theoretical perspective, when considered in isolation, can provide a very robust explanation for spatial variations in individuals' access to open space. When considered together, however, a more complete picture of the social consequences of growth can emerge.

\section{References}

Abercrombie, L. C., Sallis, J. F., Conway, T. L., Frank, L. D., Saelens, B. E., \& Chapman, J E. (2008). Income and racial disparities in access to public parks and private recreation facilities. American Journal of Preventive Medicine, 34(1), 9-15. http:// dx.doi.org/10.1016/j.amepre.2007.09.030.

Anselin, L. (1988). Spatial econometrics: Methods and models. Dordrecht, Netherlands: Kluwer Academic.

Berry, B. L. J., \& Parr, J. B. (1988). Market centers and retail location. Englewood Cliffs, NJ: Prentice Hall.

Bhatta, S. D. (2001). Are inequality and poverty harmful for economic growth: Evidence from the metropolitan areas of the United States. Journal of Urban Affairs, 23(3 and 4), 335-359. http://dx.doi.org/10.1111/0735-2166.00093.

Bird, J. (1977). Centrality and cities. London: Routledge and Kegan Paul.

Bobo, L., Kluegel, J. R., \& Smith, R. A. (1997). Laissez-faire racism: The crystallization of a kinder, gentler, antiblack Ideology. In S. A. Tuch \& J. K. Martin (Eds.), Racial attitudes in the 1990s: Continuity and change (pp. 15-42). Westport, CT: Praeger

Brownlow, A. (2006a). Inherited fragmentations and narratives of environmental control in entrepreneurial Philadelphia. In N. Heynen, E. Swyngedouw, \& M. Kaika (Eds.), In the nature of cities (pp. 208-225). New York: Routledge.

Brownlow, A. (2006b). An archaeology of fear and environmental change in Philadelphia. Geoforum, 37, 227-245.

Bullard, R. D. (2000). Dumping in dixie: Race, class and environmental quality (3rd ed.) Boulder, CO: Westview.

Byrne, J. (2012). When green is white: The cultural politics of race, nature and social exclusion in a Los Angeles urban national park. Geoforum, 43(3), 595-611. http://dx.doi.org/10.1016/j.geoforum.2011.10.002.

Byrne, J., Kendrick, M., \& Sroaf, D. (2007). The park made of oil: Toward a historical political ecology of the Kenneth Hahn State Recreation Area. Local Environment, $12,153-181$

Byrne, J., \& Wolch, J. (2009). Nature, race, and parks: Past research and future directions for geographic research. Progress in Human Geography, 1-23.

Christaller, W. (1933). Die zentralen orte in Suddeutschland (Central places in southern Germany). (C. W. Baskin, Trans.). Englewood Cliffs, NJ: Prentice Hall.

Clark, T., \& Lloyd, R. (2000). The city as an entertainment machine. Chicago, IL: University of Chicago Press.

Clark, T. N. (2000). Old and new paradigms for urban research: Globalization and the fiscal austerity and urban innovation project. Urban Affairs Review, 36(1) $3-45$.

Clark, T. N., Lloyd, R., Wong, K. K., \& Jain, P. (2002). Amenities drive urban growth. Journal of Urban Affairs, 24(5), 493-515.

Comedia/Demos (1995). Park life: Urban parks and social renewal. London: Comedia and Demos.

Cranz, G. (1982). The politics of park design: A history of urban parks in America. Cambridge, MA: MIT Press.

Cronon, W. (1991). Nature's metropolis: Chicago and the great west. New York: Norton.

Domhoff, G. W. (1990). The power elite and the state: How policy is made in America. Hawthorne, NY: Aldine de Gruyter.

Florida, R. (2002). The rise of the creative class: And how it's transforming work, leisure, community, and everyday life. New York: Basic Books.

Floyd, M. F., Bocarro, J. N., \& Thompson, T. D. (2008). Research on race and ethnicity in leisure studies: A review of five major journals. Journal of Leisure Research, $40(1), 1-22$.

Fotheringham, A. S., Brunsdon, C., \& Charlton, M. (2002). Geographically weighted regression: The analysis of spatially varying relationships. Chichester, United Kingdom: Wiley.

Fujita, M., Krugman, P., \& Venebles, A. (1999). The spatial economy: Cities, regions and international trade. Cambridge, MA: MIT Press.
Fujita, M., \& Thisse, J. F. (2002). Economies of agglomeration: Cities, industrial location and regional growth. Cambridge, United Kingdom: Cambridge University Press.

Glaeser, E. L. (2000). The new economics of urban and regional growth. In G. L. Clark, M. P. Gertler, \& M. S. Feldman (Eds.), The Oxford handbook of economic geography (pp. 83-98). Oxford, United Kingdom: Oxford University Press.

Glaeser, E. L., \& Rappaport, J. (2001). Cities and governments. In S. Yusuf, S. Evenett, \& W. Wu (Eds.), Facets of globalization: International and local dimensions of development (pp. 121-146). Washington, DC: The World Bank.

Glick, J. (2008). Gentrification and the racialized geography of home equity. Urban Affairs Review, 44(2), 280-295. http://dx.doi.org/10.1177/1078087408316971.

Godbey, G., Graefe, A., \& James, S. W. (1992). The benefits of local recreation and park services: A nationwide study of the perceptions of the American public. State College, PA: Leisure Studies Program, Pennsylvania State University for the National Recreation and Park Association.

Golledge, R. G., \& Stimson, R. J. (1997). Spatial behavior. New York: Guilford.

Hall, P. (1998). Sociable cities: The legacy of Ebenezer Howard. Chichester, United Kingdom: Wiley.

Harvey, D. (2006). The limits to capital. London: Verso.

Heynen, N. (2006). Green urban political ecologies: Toward a better understanding of inner-city environmental change. Environment and Planning A, 38(3), 499-516. http://dx.doi.org/10.1068/a37365.

Heynen, N., \& Perkins, H. A. (2005). Scalar dialects in green: Urban private property and the contradictions of neoliberalization of nature. Capitalism, Nature, Socialism, 16, 99-113.

Heynen, N., Perkins, H. A., \& Roy, P. (2006). The political ecology of uneven urban green space: The impact of political economy on race and ethnicity in producing environmental inequality in Milwaukee. Urban Affairs Review, 42(1), 3-25. http://dx.doi.org/10.1177/1078087406290729.

Hope, D., Gries, C., Zhu, W., Fagan, W. F., Redman, C. L., Grimm, N. B., \& Kinzig, A. (2003). Socioeconomics drive urban plant diversity. Proceedings of the National Academy of Sciences, 100(15), 8788-8792. http://dx.doi.org/10.1073/ pnas. 1537557100

Howard, E. (1898). Garden cities of tomorrow. London: Faber and Faber

Hsu, W.-T. (2012). Central place theory and city size distribution. Economic Journal, 122(563), 903-932. http://dx.doi.org/10.1111/j.1468-0297.2012.02518.x.

Isard, W. (1956). Location and space-economy: A general theory relating to industrial location, market areas, land use, trade and urban structure. Cambridge, MA: MIT Press.

Iverson, L. R., \& Cook, E. A. (2000). Urban forest cover of the Chicago region and its relation to household density and income. Urban Ecosystems, 4(2), 105-124. http://dx.doi.org/10.1023/A:1011307327314.

Kaplan, R., \& Kaplan, S. (1989). Experience and nature: A psychological perspective. New York: Cambridge University Press.

Katz, C., \& Kirby, A. (1991). In the nature of things: The environment and everyday life. Transactions of the Institute of British Geographers, 16, 259-271.

Kendal, D., Williams, N. S. G., \& Williams, K. J. H. (2012). Drivers of diversity and tree cover in gardens, parks and streetscapes in an Australian city. Urban Forestry E Urban Greening, 11(3), 257-265. http://dx.doi.org/10.1016/j.ufug.2012.03.005.

King, L. J. (1984). Central place theory. Beverly Hills, CA: Sage.

Koehler, D. H., \& Wrightson, M. T. (1987). Inequality in the delivery of urban services: A reconsideration of the Chicago parks. The Journal of Politics, 49(01), 80-99. http://dx.doi.org/10.2307/2131135.

Korpi, M. (2008). Does size of local labour markets affect wage inequality? A rank-size rule of income distribution. Journal of Economic Geography, 8(2), 211-237.

Krugman, P. (1991). Geography and trade. Cambridge, MA: MIT Press.

Krugman, P. (1993). First nature, second nature, and metropolitan location. Journal of Regional Science, 33(2), 129-144.

Lee, S.-W., Taylor, P. D., \& Hong, S.-K. (2008). Moderating effects of forest cover on the effect of proximity to chemical facilities on property values. Landscape and Urban Planning, 86(2), 171-176.

Logan, J. R. (1976). Industrialization and the stratification of cities and suburban regions. The American Journal of Sociology, 82(2), 333-348.

Logan, J. R., \& Molotch, H. L. (2007). Urban fortunes: The political economy of place. Berkeley, CA: University of California Press.

Lösch, A. (1941). Die raumliche ordnung der wirtshcaft (The economics of location). (W. H. Woglom, Trans.). New Haven, CT: Yale University.

Lubbe, C. S., Siebert, S. J., \& Cilliers, S. S. (2010). Political legacy of South Africa affects the plant diversity patterns of urban domestic gardens along a socio-economic gradient. Scientific Research and Essays, 5(19), 2900-2910.

Madge, C. (1997). Public parks and the geography of fear. Tijdschrift Voor Economische En Sociale Geografie, 88, 237-250.

Mayberry, R. M., Mili, F., \& Ofili, E. (2000). Racial and ethnic differences in access to medical care. Medical Care Research and Review, 57(S1), 108-145.

McCann, P., \& Van Oort, F. (2009). Theories of agglomeration and regional economic growth: A historical review. In R. Capello \& P. Nijkamp (Eds.), Handbook of regional growth and development theories (pp. 19-52). Cheltenham, United Kingdom: Edward Elgar Publishing Limited.

McIntosh, P. (2004). White privilege: Unpacking the invisible knapsack. In P. S. Rothenberg (Ed.), Race, class, and gender in the United States (6th ed., pp. 188-192). New York: Worth.

Mennis, J. (2006). Socioeconomic-vegetation relationships in urban, residential land: The case of Denver, Colorado. Photogrammetric Engineering and Remote Sensing, 72(8), 911-921. 
Mladenka, K. R. (1980). The urban bureaucracy and the Chicago political machine: Who gets what and the limits of political control. The American Political Science Review, 74, 991-998.

Moller, S., Alderson, A. S., \& Nielsen, F. (2009). Changing patterns of income inequality in US counties, 1970-2000. American Journal of Sociology, 114(4), 1037-1101.

Molotch, H. (1976). The city as a growth machine: Toward a political economy of place. American Journal of Sociology, 82(2), 309-332.

Mulligan, G. F. (1984). Agglomeration and central place theory: A review of the literature. International Regional Science Review, 9, 1-42.

Mulligan, G. F., Partridge, M. D., \& Carruthers, J. I. (2012). Central place theory and its reemergence in regional science. Annals of Regional Science, 48(2), 405-431. http://dx.doi.org/10.1007/s00168-011-0496-7.

Noe, F. P., \& Snow, R. (1989). Hispanic cultural influence on environmental concern. Journal of Environmental Education, 21, 27-34.

Pastor, M., Sadd, J., \& Hipp, J. (2001). Which came first? Toxic facilities, minority move-in, and environmental justice. Journal of Urban Affairs, 23(1), 1-21.

Porter, M. (1998). On competition: Competing across locations. Cambridge, MA: Harvard Business School Press.

Powell, L. M., Slater, S., \& Chaloupka, F. J. (2004). The relationship between community physical activity settings and race, ethnicity and socioeconomic status. Evidence-Based Preventitive Medicine, 1(2), 135-144.

Pulido, L. (2000). Rethinking environmental racism: White privilege and urban development in southern California. Annals of the Association of American Geographers, 90(1), 12-40. http://dx.doi.org/10.1111/0004-5608.00182.

Rushton, G. (1969). Analysis of spatial behavior by revealed space preference. Annals of the American Association of Geographers, 57, 391-400.

Ryan, B. D., \& Weber, R. D. (2007). Valuing new development in distressed urban neighborhoods: Does design matter? Journal of the American Planning Association, 73(1), 100-111.

Sassen, S. (2001). The global city: New York, London, Tokyo. Princeton, NJ: Princeton University Press.

Shinew, K. J., Stodolska, M., Floyd, M. F., Hibbler, D., Allison, M., Johnson, C., \& Santos, C. (2006). Race and ethnicity in leisure behavior: Where have we been and where do we need to go? Leisure Sciences, 28(4), 403-408.
Squires, G. D. (2003). Racial profiling, insurance style: Insurance redlining and uneven development of metropolitan areas. Journal of Urban Affairs, 25(4), $391-410$.

Stuart, G. (2003). Discriminating risk: The US mortgage lending industry in the 20th century. Ithaca, NY: Cornell University Press.

Tajima, K. (2003). New estimates of the demand for urban green space: Implications for valuing the environmental benefits of Boston's Big Dig Project. Journal of Urban Affairs, 25(5), 641-655. http://dx.doi.org/10.1111/j.14679906.2003.00006.x.

Talarchek, G. (1990). The urban forest of New Orleans: An exploratory analysis of relationships. Urban Geography, 11(1), 65-86. http://dx.doi.org/10.2747/02723638.11.1.65.

Tierney, P. T., Dahl, R., \& Chavez, D. J. (2001). Cultural diversity in use of undeveloped natural areas by Los Angeles county residents. Tourism Management, 22, 271-277.

Tisdale, H. (1942). The process of urbanization. Social Forces, 20(3), 311-316

Ullman, E. (1941). A theory of location for cities. American Journal of Sociology, 46(6), 853-864. http://dx.doi.org/10.2307/2769394.

Ward Thompson, C. (1996). Updating Olmstead. Landscape Design, 254, 26-31.

Ward Thompson, C. (2002). Urban open space in the 21st century. Landscape and Urban Planning, 60(2), 59-72.

Weber, A. (1909). Theory of the location of industries. Chicago, IL: University of Chicago Press.

Wen, M., Zhang, X., Harris, C. D., Holt, J. B., \& Croft, J. B. (2013). Spatial disparities in the distribution of parks and green spaces in the USA. Annals of Behavioral Medicine, 45(S1), S18-S27.

Whitzman, C. (2002). Feminist activism for safer social space in high park, Toronto: How women got lost in the woods. Canadian Journal of Urban Research, 11 299-321.

Willems-Braun, B. (1997). Buried epistemologies: The politics of nature in (post) colonial British Columbia. Annals of the Association of American Geographers, 87, 3-31.

Wolch, J., Wilson, J., \& Fehrenbach, J. (2005). Parks and park funding in Los Angeles: An equity-mapping analysis. Urban Geography, 26(1), 4-35. http://dx.doi.org/ 10.2747/0272-3638.26.1.4. 